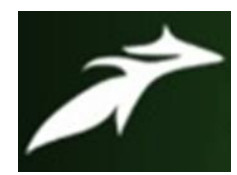

Ravi Prakash Verma et al, International Journal of Advances in Agricultural Science and Technology,

Vol.8 Issue.8, August-2021, pg. 16-32

\title{
Knowledge and Adoption of Mentha Growers Regarding Recommended Cultivation Practices of Mentha Crop in Siddhaur Block of Barabanki District Uttar Pradesh
}

\author{
Ravi Prakash Verma' ${ }^{1}$ Prof. (Dr.) Jahanara ${ }^{2}$; Dr. Dipak Kumar Bose \\ ${ }^{1}$ M.Sc. Ag. (Agricultural Extension and communication), SHUATS (Prayagraj) \\ ${ }^{2}$ Head, Department of Agriculture Extension and Communication, SHUATS (Prayagraj) \\ ${ }^{3}$ Associate Professor, Department of Agriculture Extension and Communication, SHUATS (Prayagraj) \\ Author's e-mail: ravi.racer7@gmail.com \\ DOI: 10.47856/ijaast.2021.v08i8.002
}

\begin{abstract}
This study was conducted in Siddhaur block of Barabanki district of Uttar Pradesh in 2020-2021. With the help of random sampling method, 120 Mentha growers were selected and data were collected by personal interview method by using pre-tested interview schedule and later appropriate statistical analysis was done to find out the meaningful result. The finding of the study revealed that the overall level of knowledge of mentha growers regarding the recommended practices indicated they have medium knowledge level. The Adoption level of mentha growers on recommended cultivation practices of mentha also indicated as medium level of adoption $(66.70 \%)$, followed by low level of adoption (21.70\%) and high level of adoption (11.60\%).
\end{abstract}

Keywords: Knowledge, Adoption, Recommended cultivation of Mentha

\section{Introduction}

Mentha (Mentha arvensis) popularly known as mint or pudina is an aromatic herb having pleasant odour leaves. Mentha is also considered as country's breadbasket, plays an important role in the export. Mentha oil is the major derivative of mentha leaves is of very high economic and medicinal value. Mints belong to the genus Mentha, in the family Labiatae (Lamiaceae) which includes other commonly grown essential oil-yielding plants such as basil, sage, rosemary, marjoram, lavender, pennyroyal and thyme. Within the genus Mentha there are several commercially grown species, varying in their major chemical content, aroma and end use. Their oils and derived aroma compounds are traded world-wide. 


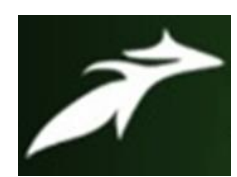

Ravi Prakash Verma et al, International Journal of Advances in Agricultural Science and Technology, Vol.8 Issue.8, August-2021, pg. 16-32

ISSN: 2348-1358

Impact Factor: 6.057

NAAS Rating: 3.77

Mentha (Mentha arvensis) popularly known as mint or pudina is an aromatic herb having pleasant odour leaves. Mentha is also considered as country's breadbasket, plays an important role in the export. Mentha oil is the major derivative of mentha leaves is of very high economic and medicinal value. Mints belong to the genus Mentha, in the family Labiatae (Lamiaceae) which includes other commonly grown essential oil-yielding plants such as basil, sage, rosemary, marjoram, lavender, pennyroyal and thyme. Within the genus Mentha there are several commercially grown species, varying in their major chemical content, aroma and end use. Their oils and derived aroma compounds are traded world-wide.

The menthol content was varied from $32.92 \%-42.83 \%$ in the above-mentioned cultivar (Singh et al., 2007). Menthol mint is cultivated in a large area in the Indo-Gangetic plains in the states of Punjab, Haryana, Uttarakhand, Uttar Pradesh and Bihar (Khanuja et al., 2005). The major districts in Uttar Pradesh where this crop is being cultivated are Badaun, Bareilly, Sahajanpur, Pilibhit, Lakhimpur Khiri, Barabanki and Ambedkar Nagar (Kumar et al., 2011). Now this crop has been cultivated in all the districts of Uttar Pradesh along with entire north India region.

\section{Research Methodology}

The present study was conducted in the District Barabanki in the East direction of Lucknow the Capital of Uttar Pradesh.Out of 17 blocks in Barabanki district in Uttar Pradesh, Siddhaur block is selected purposively for present study.

In Siddhaur block of Barabanki district, there were one hundred and sixty-nine villages. Out of which, six villages were selected purposively where maximum number of farmers grow mentha. The list of selected villages was Arui, Budhani, Jalalpur, Sarsa, Usmanpur and Siddhaur. The structured interview schedule was prepared for data collection. Descriptive research design was used for this study. The statistical tools like frequency, percentage, mean, standard deviation were used to interpret the data and for drawing logical conclusion. 


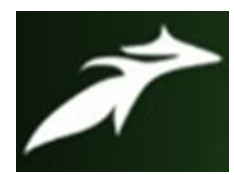

Ravi Prakash Verma et al, International Journal of Advances in Agricultural Science and Technology, Vol.8 Issue.8, August-2021, pg. 16-32

ISSN: 2348-1358

Impact Factor: 6.057

NAAS Rating: 3.77

\section{Measurement of Knowledge}

Knowledge and adoption about recommended practices of Mentha cultivation

In the present study, knowledge has been operationally defined as the body of awareness and understood information possessed by an individual mentha grower about mentha cultivation practices.It is the degree to which the factual information is possessed by the respondent regarding farming experiences. The responses were recorded on three-point continuum as fully correct, partially correct and not correct as 3,2 and 1 respectively.most of the respondents had medium knowledge (51.70\%), followed by low level of knowledge (33.30\%) and high level of knowledge (15\%)..For Adoption, The responses of adoption regarding recommended cultivation practices of mentha was recorded on three point continuum as fully adopted, partially adopted and not adopted as 3, 2 and 1 respectively. most of the respondent had medium level of adoption (66.70\%), followed by low level of adoption (21.70\%) and high level of adoption (11.60\%).

\section{RESULTS AND DISCUSSIONS}

Table 1. Socio-economic profile characteristics of the mentha growers

\begin{tabular}{|c|c|c|c|c|c|}
\hline S.No. & $\begin{array}{c}\text { Independent } \\
\text { variable }\end{array}$ & \multicolumn{2}{|c|}{ Category } & Frequency & Percentage \\
\hline \multirow[t]{3}{*}{1} & Age & \multicolumn{2}{|c|}{ Young age group } & 14 & 11.70 \\
\hline & & \multicolumn{2}{|c|}{ Middle age group } & 98 & 81.70 \\
\hline & & \multicolumn{2}{|c|}{ Old age group } & 8 & 6.60 \\
\hline \multirow[t]{4}{*}{2} & Education & \multicolumn{2}{|c|}{ Illiterate } & 26 & 21.70 \\
\hline & & \multicolumn{2}{|c|}{ Primary and secondary } & 56 & 46.60 \\
\hline & & \multicolumn{2}{|c|}{ High School } & 26 & 21.70 \\
\hline & & \multicolumn{2}{|c|}{ Graduate and diploma } & 12 & 10.00 \\
\hline \multirow[t]{2}{*}{3} & Occupation & Agriculture & Main occupation & 98 & 81.7 \\
\hline & & & $\begin{array}{l}\text { Subsidiary } \\
\text { occupation }\end{array}$ & 22 & 18.3 \\
\hline
\end{tabular}




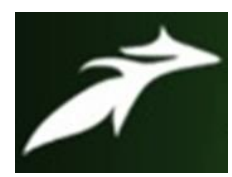

Ravi Prakash Verma et al, International Journal of Advances in Agricultural Science and Technology, Vol.8 Issue.8, August-2021, pg. 16-32

ISSN: 2348-1358

Impact Factor: 6.057

NAAS Rating: 3.77

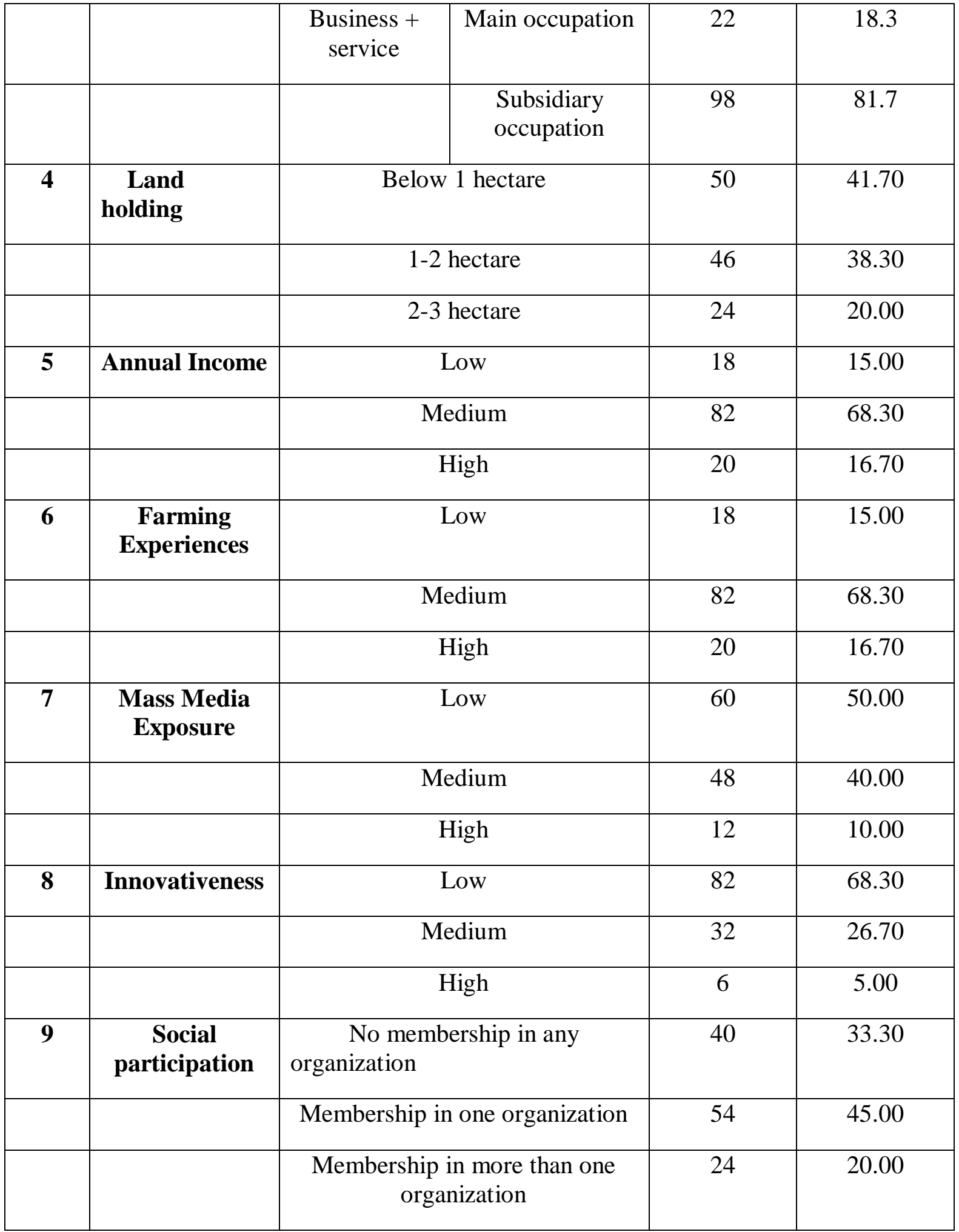




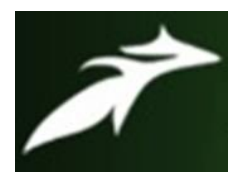

Ravi Prakash Verma et al, International Journal of Advances in Agricultural Science and Technology, Vol.8 Issue.8, August-2021, pg. 16-32

ISSN: 2348-1358 Impact Factor: 6.057

NAAS Rating: 3.77

\begin{tabular}{|c|l|c|c|c|}
\hline & & Office bearer & 2 & 1.70 \\
\hline $\mathbf{1 0}$ & $\begin{array}{l}\text { Risk } \\
\text { orientation }\end{array}$ & Low & 26 & 21.67 \\
\hline $\mathbf{1 1}$ & $\begin{array}{l}\text { Economic } \\
\text { motivation }\end{array}$ & Medium & 79 & 65.83 \\
\hline & Low & 15 & 12.50 \\
\hline $\mathbf{1 2}$ & $\begin{array}{l}\text { Extension } \\
\text { contacts }\end{array}$ & Medium & 30 & 25.00 \\
\hline & & High & 28 & 23.30 \\
\hline & & Medium & 74 & 28.33 \\
\hline
\end{tabular}

The table 1 above shows that 81.70 per cent of the respondent belonged to the age group of middle age. Majority of the respondents i.e. 46.60 percent have primary and secondary level of education.81.70 percent of the respondents depends agriculture as the main occupation .In terms of land holdings, 41.70 percent respondents having land below 1 hectre. 68.30 percent of respondents are having a medium level of annual income. It is evident that 68.30 percent of respondents are having medium farming experiences. Only 50 percent of respondents are exposed to mass media exposure.68.30 percent of respondents having low level of innovativeness. In terms of social participation 45 percent respondents are having membership in any one organization.58.33 percent of respondents having medium level of extension contact.

Knowledge level of mentha growers on recommended cultivation practices of mentha and the results were presented in table 2 . 


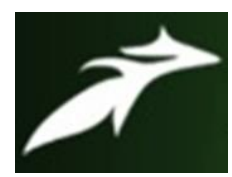

Ravi Prakash Verma et al, International Journal of Advances in Agricultural Science and Technology, Vol.8 Issue.8, August-2021, pg. 16-32

ISSN: 2348-1358

Impact Factor: 6.057

NAAS Rating: 3.77

Table.2. Distribution of mentha growers according to their knowledge level

\begin{tabular}{|c|c|c|c|c|c|c|c|}
\hline \multirow{3}{*}{$\begin{array}{c}\text { Sl. } \\
\text { No. }\end{array}$} & \multirow[t]{3}{*}{ Statement } & \multicolumn{6}{|c|}{ Evaluation } \\
\hline & & \multicolumn{2}{|c|}{ Fully correct } & \multicolumn{2}{|c|}{ Partially correct } & \multicolumn{2}{|c|}{ Not correct } \\
\hline & & $f$ & $\%$ & $f$ & $\%$ & $f$ & $\%$ \\
\hline 1. & $\begin{array}{l}\text { Field preparation: } \\
\text { i.Traditional method- 2-3 } \\
\text { times ploughing and } \\
\text { harrowing } \\
\text { ii. Use of zero tillage } \\
\text { machine }\end{array}$ & 21 & 17.50 & 43 & 35.83 & 56 & 46.67 \\
\hline 2. & \begin{tabular}{|rl}
\multicolumn{2}{c}{ Improved variety: } \\
I. & MAS 1 \\
II. & Hybrid 77 \\
III. & EC 41911 \\
IV. & Kalka \\
V. & Gomti \\
VI. & Himalaya \\
VII. & Kosi
\end{tabular} & 12 & 10.00 & 81 & 67.50 & 27 & 22.50 \\
\hline 3. & $\begin{array}{l}\text { Seed and its treatment: } \\
\text { I. Agallol }(0.1 \%) \\
\text { II. Captan sol. }\end{array}$ & 27 & 22.50 & 80 & 66.67 & 13 & 10.83 \\
\hline 4. & $\begin{array}{l}\text { Sowing time: } \\
\text { I. } \quad \begin{array}{l}\text { Last week of Dec } \\
\text { to } 1 \text { week of march }\end{array} \\
\text { II. } \quad \begin{array}{l}\text { 1 Week of Jan to } 3 \\
\text { week of Feb }\end{array}\end{array}$ & 11 & 9.17 & 82 & 68.33 & 27 & 22.50 \\
\hline 5. & $\begin{array}{l}\text { Spacing: } \\
\text { I. } \quad 40 \mathrm{~cm} \times 10 \mathrm{~cm} \\
\text { II. } \quad 60 \mathrm{~cm} \times 15 \mathrm{~cm}\end{array}$ & 18 & 15.00 & 70 & 58.33 & 32 & 26.67 \\
\hline
\end{tabular}




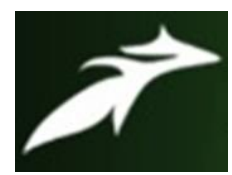

Ravi Prakash Verma et al, International Journal of Advances in Agricultural Science and Technology, Vol.8 Issue.8, August-2021, pg. 16-32

ISSN: 2348-1358

Impact Factor: 6.057

NAAS Rating: $\mathbf{3 . 7 7}$

\begin{tabular}{|c|c|c|c|c|c|c|c|}
\hline 6. & $\begin{array}{l}\text { Fertilizers: } \\
\begin{array}{ll}\text { I. } \quad 40: 60: 40 \mathrm{Kg} \\
\\
\\
\text { NPK/ha }\end{array}\end{array}$ & 27 & 22.50 & 48 & 40.00 & 45 & 37.50 \\
\hline 7. & $\begin{array}{l}\text { Irrigation: } \\
\text { I. } \quad 5 \text { times } \\
\text { II. } \quad 6 \text { times } \\
\text { III. } \quad 8 \text { times } \\
\text { IV. } \quad 9 \text { times }\end{array}$ & 16 & 13.33 & 71 & 59.17 & 33 & 27.50 \\
\hline 8. & $\begin{array}{l}\text { Weeding and hoeing } \\
\text { operations: } \\
\text { I. 2times } \\
\text { II. 3times } \\
\text { III. } \quad \text { times }\end{array}$ & 13 & 10.83 & 59 & 49.17 & 48 & 40.00 \\
\hline 9. & $\begin{array}{ll}\text { Weed control: } \\
\text { I. } & \text { Sulfosulfuron } \\
\text { II. } & \text { Metribuzin } \\
\text { III. } & \text { Clodinafop } \\
\text { IV. } & \text { Fenoxaprop-p-ethyl }\end{array}$ & 21 & 17.50 & 62 & 51.67 & 37 & 30.83 \\
\hline 10. & \begin{aligned} & \multicolumn{2}{l}{ Diseases: } \\
& I. Rust \\
& II. Stolon decay \\
& III. Verticillium wilt \\
& IV. Septoria leaf spot \end{aligned} & 24 & 20.00 & 68 & 56.67 & 28 & 23.33 \\
\hline 11. & $\begin{array}{ll}\text { Harvesting: } \\
\text { I. } & \text { 80-90days } \\
\text { II. } & 90-100 \text { days } \\
\text { III. } & 100-110 \text { days } \\
\text { IV. } & 110-120 \text { days }\end{array}$ & 13 & 10.83 & 69 & 57.50 & 38 & 31.67 \\
\hline 12. & 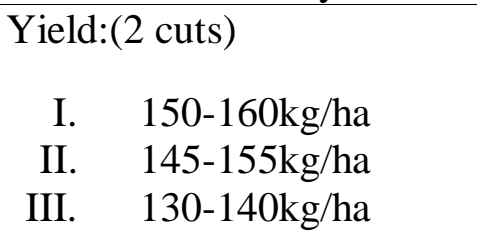 & 21 & 17.50 & 54 & 45.00 & 45 & 37.50 \\
\hline
\end{tabular}

Table.2, interprets that 46.67 per cent of the respondents had no knowledge on field preparation, followed by 35.83 per cent had partial correct knowledge and 17.50 per cent of 


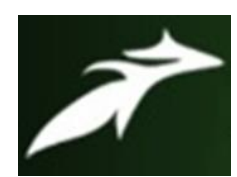

Ravi Prakash Verma et al, International Journal of Advances in Agricultural Science and Technology, Vol.8 Issue.8, August-2021, pg. 16-32

ISSN: 2348-1358

Impact Factor: 6.057

NAAS Rating: 3.77

the respondents had knowledge on field preparation. Whereas, 67.50 per cent of the respondents had knowledge on improved variety, 22.50 per cent had no knowledge on improved variety and 10 per cent had knowledge on improved variety. With reference to seed and its treatments, 66.67 per cent had partial knowledge, followed by 22.50 per cent had knowledge and 10.83 per cent had no knowledge. 68.33 per cent of the respondents had partial knowledge on sowing time, followed by 22.50 per cent had no knowledge and 9.17 per cent had knowledge on sowing time. Regarding spacing, more than half of the respondents (58.33\%) had partial knowledge, followed by 26.67 per cent of the respondents had no knowledge and 15 per cent of the respondents had knowledge.

Meanwhile, 40 per cent of the respondents has partial knowledge on fertilizers, followed by 37.50 per cent of the respondents had no knowledge and 22.50 per cent of them had knowledge on fertilizers. 59.17 per cent of the respondents had medium knowledge on irrigation, followed by 27.50 per cent of the respondents had no knowledge and 13.33 per cent of the respondents had knowledge on irrigation. Similarly, 49.17 per cent of the respondents had partial knowledge on weeding and hoeing operations, 40 per cent of the respondents had no knowledge and only 10.83 per cent of them had knowledge on weeding and hoeing operations.

Similarly, half of the respondents (51.67\%) had partial knowledge, 30.83 per cent had no knowledge and 17.50 per cent had knowledge on weed control respectively. With reference to diseases, 56.67 per cent of the respondents had medium knowledge, 23.33 per cent had no knowledge and 20 per cent had knowledge on diseases. More than half $(57.50 \%)$ of the respondents had partial knowledge, 31.67 per cent had no knowledge and 10.83 per cent had knowledge on harvesting respectively. Whereas, 45 per cent of the respondents had partial knowledge, 37.50 per cent of the respondents had no knowledge and only 17.50 per cent of the respondents had knowledge on yield. 


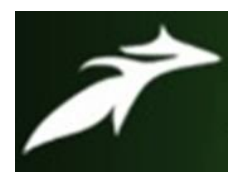

Ravi Prakash Verma et al, International Journal of Advances in Agricultural Science and Technology, Vol.8 Issue.8, August-2021, pg. 16-32

ISSN: $2348-1358$

Impact Factor: 6.057

NAAS Rating: 3.77

Table.3 Distribution of mentha growers according to their overall knowledge level

\begin{tabular}{|c|c|c|c|}
\hline S. No. & Category & Frequency & Per cent \\
\hline 1 & Low knowledge & 40 & 33.30 \\
\hline 2 & Medium knowledge & 62 & 51.70 \\
\hline 3 & High knowledge & 18 & 15.00 \\
\hline \multicolumn{2}{|l|}{ Total } & 120 & 100.00 \\
\hline
\end{tabular}

The results regarding knowledge about the recommended cultivation of mentha table 3 and fig. 1 indicated that most of the respondents had medium knowledge $(51.70 \%)$, followed by low level of knowledge (33.30\%) and high level of knowledge (15\%). The probable reason might be the interest in knowing about the recommended cultivation practices in mentha and their eagerness to learn about new knowledge or technology which is related to Mentha cultivation.

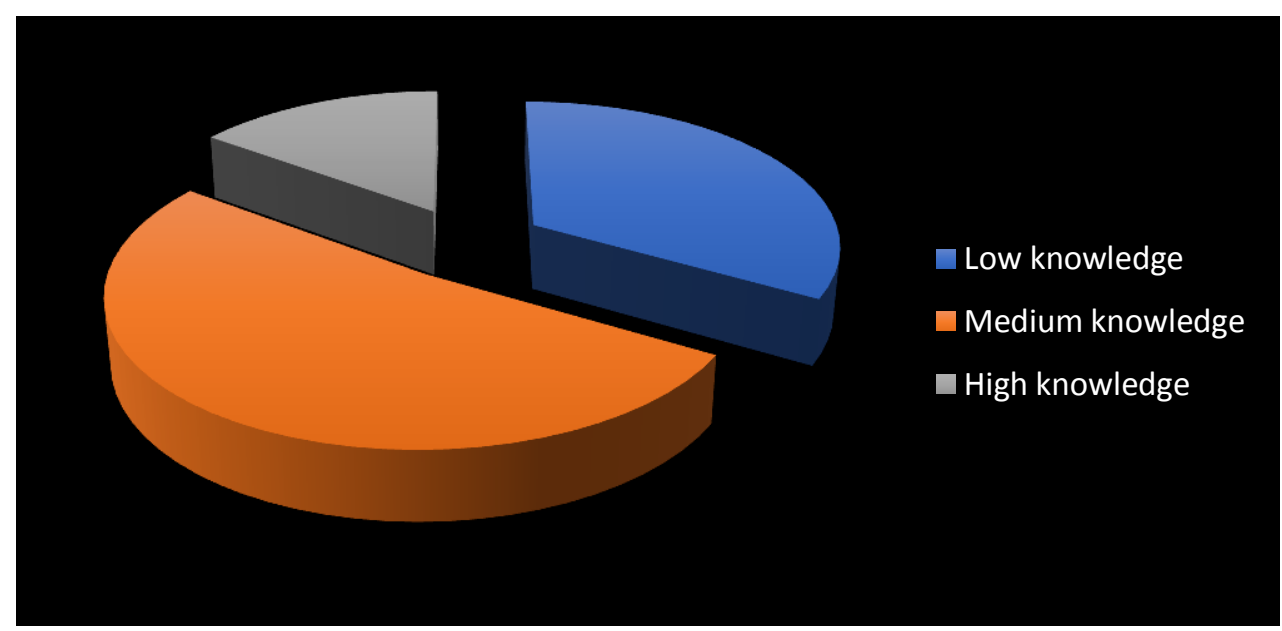




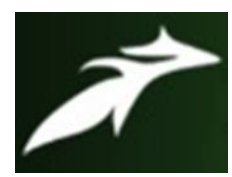

Ravi Prakash Verma et al, International Journal of Advances in Agricultural Science and Technology, Vol.8 Issue.8, August-2021, pg. 16-32

ISSN: 2348-1358

Impact Factor: 6.057

NAAS Rating: $\mathbf{3 . 7 7}$

Table.4. Adoption level of mentha growers about recommended cultivation practices of mentha

\begin{tabular}{|c|c|c|c|c|c|c|c|}
\hline \multirow{3}{*}{ S. No. } & \multirow{3}{*}{\begin{tabular}{|c|} 
Recommended \\
improved \\
cultivation practices
\end{tabular}} & \multicolumn{6}{|c|}{ Responses } \\
\hline & & \multicolumn{2}{|c|}{ Fully adopted } & \multicolumn{2}{|c|}{$\begin{array}{l}\text { Partially } \\
\text { adopted }\end{array}$} & \multicolumn{2}{|c|}{ Not adopted } \\
\hline & & $f$ & $\%$ & $f$ & $\%$ & $f$ & $\%$ \\
\hline 1. & Varieties sowing & 11 & 9.17 & 93 & 77.50 & 16 & 13.33 \\
\hline 2. & Nursery Sowing time: & 17 & 14.17 & 71 & 59.17 & 32 & 26.67 \\
\hline 3. & $\begin{array}{l}\text { Planting time : } \\
\text { (a) Early- } \\
\text { (b) Mid- } \\
\text { (c) Late- }\end{array}$ & 9 & 7.50 & 76 & 63.33 & 35 & 29.17 \\
\hline 4. & Seed treatment: & 18 & 15.00 & 71 & 59.17 & 31 & 25.83 \\
\hline 5. & $\begin{array}{l}\text { Seed rate : } \\
\text { (a)Early- } \\
\text { (b)Mid } \\
\text { (c) Late- }\end{array}$ & 8 & 6.67 & 101 & 84.17 & 11 & 9.17 \\
\hline
\end{tabular}




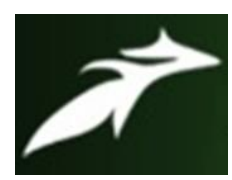

Ravi Prakash Verma et al, International Journal of Advances in Agricultural Science and Technology, Vol.8 Issue.8, August-2021, pg. 16-32

ISSN: 2348-1358

Impact Factor: 6.057

NAAS Rating: $\mathbf{3 . 7 7}$

\begin{tabular}{|c|c|c|c|c|c|c|c|}
\hline 6. & $\begin{array}{l}\text { Source of seed } \\
\text { material : } \\
\text { a)Private shop } \\
\text { b) Government center } \\
\text { c)From Agriculture } \\
\text { research station }\end{array}$ & 6 & 5.00 & 87 & 72.50 & 27 & 22.50 \\
\hline 7. & $\begin{array}{l}\text { Method of sowing } \\
\text { followed : } \\
\text { a)Seeding } \\
\text { b)Transplanting }\end{array}$ & 16 & 13.33 & 70 & 58.33 & 34 & 28.33 \\
\hline 8. & $\begin{array}{l}\text { Spacing adopted } \\
\text { (a) Early- } \\
\text { (b) Mid- } \\
\text { (c) Late- }\end{array}$ & 33 & 27.50 & 55 & 45.83 & 32 & 26.67 \\
\hline 9. & $\begin{array}{l}\text { Chemical Fertilizer } \\
\text { and manure } \\
\text { management: } \\
\text { a)FYM - } \\
\text { b)Nitrogen- } \\
\text { c)Phosphorus- } \\
\text { d)Potassium- }\end{array}$ & 12 & 10.00 & 89 & 74.17 & 19 & 15.83 \\
\hline 10. & Inter cultivation & 5 & 4.17 & 97 & 80.83 & 18 & 15.00 \\
\hline
\end{tabular}




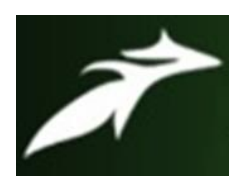

Ravi Prakash Verma et al, International Journal of Advances in Agricultural Science and Technology, Vol.8 Issue.8, August-2021, pg. 16-32

ISSN: 2348-1358

Impact Factor: 6.057

NAAS Rating: 3.77

\begin{tabular}{|c|l|c|c|c|c|c|c|}
\hline 11. & Weed management: & 29 & 24.17 & 80 & 66.67 & 11 & 9.17 \\
Pre planting- & $\begin{array}{l}\text { Post Planting- } \\
\text { Hand Weeding }\end{array}$ & 5 & 4.17 & 81 & 67.50 & 34 & 28.33 \\
\hline 12. & $\begin{array}{l}\text { Plant protection } \\
\text { measures: }\end{array}$ & 5 & 12.50 & 86 & 71.67 & 19 & 15.83 \\
\hline 13 & $\begin{array}{l}\text { Yield:- } \\
\text { i)Early : } \\
\text { ii) Medium: } \\
\text { iii) Late: }\end{array}$ & 15 & & & & & \\
\hline
\end{tabular}

Table.4. reported that 77.50 per cent of the respondents partially adopted varieties for sowing, followed by 13.33 per cent had not adopted and only 9.17 per cent adopted varieties for sowing. More than half of the respondents (59.17\%) had partially adopted, 26.67 per cent not adopted and 14.17 per cent fully adopted nursery sowing time. Meanwhile, 63.33 per cent partially adopted, 29.17 per cent not adopted and only 7.50 per cent fully adopted planting time. 59.17 per cent of the respondents had partially adopted, 25.83 per cent of the respondents not adopted and only 15 per cent of the respondents fully adopted seed treatment practices. More than three-fourth of the respondents $(84.17 \%)$ had partially adopted, 9.17 per cent not adopted and only 6.67 per cent fully adopted seed rate techniques.

Meanwhile, a higher percentage of the respondents (72.50\%) had partially adopted, 22.50 per cent not adopted and only 5 per cent fully adopted source of feed material. More than half of the respondents (58.33\%) partially adopted, 28.33 per cent not adopted, 13.33 per cent fully adopted the method of sowing. Whereas, 45.83 per cent of the respondents partially adopted, 27.50 per cent fully adopted and 26.67 per cent not adopted spacing related practices. Nearly three-fourth of the respondents $(74.17 \%)$ had partially adopted, 15.83 per cent had not adopted and only 10 per cent had fully adopted chemical fertilizer and manure management.

Similarly, 80.83 per cent of the respondents had partially adopted, 15 per cent not adopted and only 4.17 per cent fully adopted intercultivation practices. More than two-third of the 


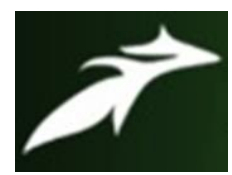

Ravi Prakash Verma et al, International Journal of Advances in Agricultural Science and Technology, Vol.8 Issue.8, August-2021, pg. 16-32

ISSN: 2348-1358

Impact Factor: 6.057

NAAS Rating: 3.77

respondents (66.67\%) had partially adopted, 24.17 per cent had fully adopted and only 9.17 per cent not adopted weed management practices. More than half of the respondents (67.50\%) had partially adopted, 28.33 per cent had not adopted and only 4.17 per cent had fully adopted plant protection measures. Eventually, 71.67 per cent of the respondents partially adopted, 15.83 per cent not adopted and only 12.50 per cent fully adopted yield related practices respectively

Table 5. and Fig. 1Distribution of mentha growers according to their overall adoption

level

\begin{tabular}{|c|c|c|c|}
\hline S. No. & Category & Frequency & Per cent \\
\hline 1 & Low adoption & 26 & 21.70 \\
\hline 2 & Medium adoption & 80 & 66.70 \\
\hline 3 & High adoption & 7 & 11.60 \\
\hline & Total & 120 & 100.00 \\
\hline
\end{tabular}

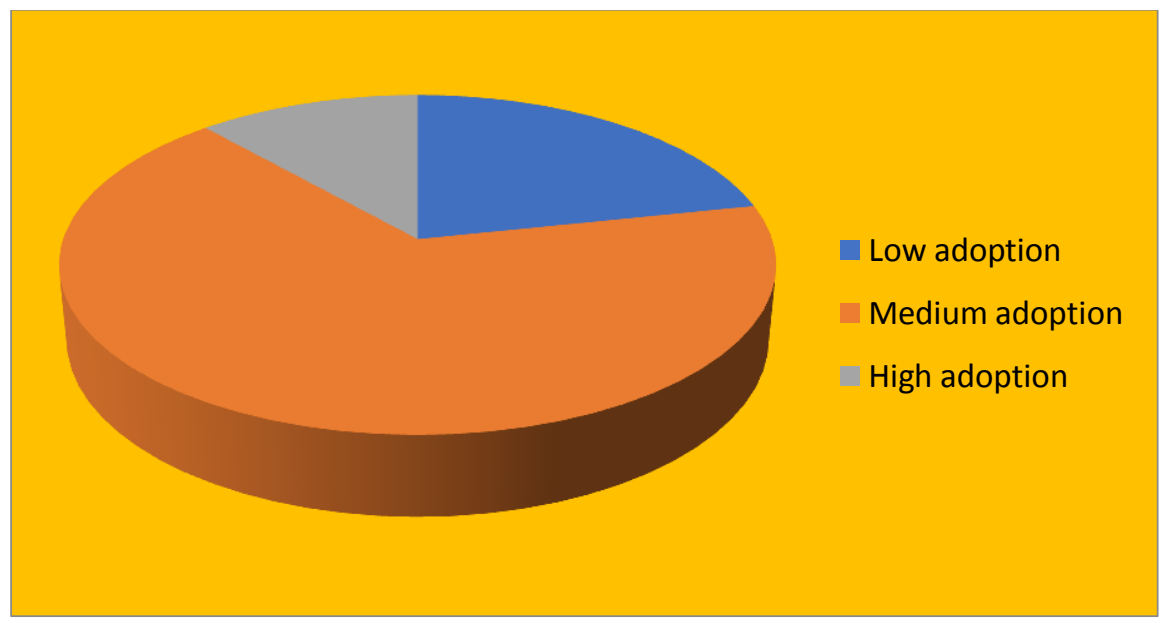




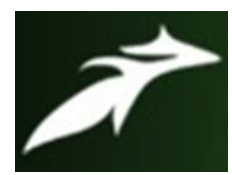

Ravi Prakash Verma et al, International Journal of Advances in Agricultural Science and Technology, Vol.8 Issue.8, August-2021, pg. 16-32

ISSN: 2348-1358

Impact Factor: 6.057

NAAS Rating: $\mathbf{3 . 7 7}$

Table 6 .Association between the independent variables and knowledge level of the farmers about recommended mentha cultivation practices

\begin{tabular}{|c|c|c|c|c|c|}
\hline $\begin{array}{c}\text { S. } \\
\text { No. }\end{array}$ & Characteristics & 'r' value & $\begin{array}{l}\text { Regression } \\
\text { co-efficient }\end{array}$ & $\begin{array}{c}\text { Standard } \\
\text { error }\end{array}$ & t-value \\
\hline $\mathrm{X}_{1}$ & Age & -0.551 & -0.22 & 0.140 & 0.873 \\
\hline $\mathrm{X}_{2}$ & Education & $0.012 *$ & $1.326^{*}$ & 0.596 & $0.031 *$ \\
\hline $\mathrm{X}_{3}$ & Land holding size & $0.054 *$ & $0.880^{* *}$ & 2.373 & $0.508 * *$ \\
\hline $\mathrm{X}_{4}$ & Occupation & 0.354 & 5.408 & 7.942 & 0.499 \\
\hline $\mathrm{X}_{5}$ & Annual income & $0.041^{*}$ & $4.065 * *$ & 5.590 & $0.471 * *$ \\
\hline $\mathrm{X}_{6}$ & Farming experience & $0.027 *$ & $6.372 * *$ & 0.000 & $0.131 * *$ \\
\hline $\mathrm{X}_{7}$ & Mass media exposure & $0.030 *$ & $-3.805^{*}$ & 1.774 & $0.037 *$ \\
\hline $\mathrm{X}_{8}$ & Innovativeness & 0.857 & -2.986 & 0.000 & 0.620 \\
\hline $\mathrm{X}_{9}$ & Social participation & $0.022 *$ & $3.863^{*}$ & 1.894 & $0.047 *$ \\
\hline $\mathrm{X}_{10}$ & Economic motivation & $0.045^{*}$ & $3.465^{*}$ & 1.682 & $0.045^{*}$ \\
\hline $\mathrm{X}_{11}$ & Risk orientation & $0.036^{*}$ & $2.435^{*}$ & 1.623 & $0.127^{*}$ \\
\hline $\mathrm{X}_{12}$ & Extension contact & $0.019 *$ & $2.674 *$ & 1.143 & $0.096^{*}$ \\
\hline
\end{tabular}

NS $=$ Not Significant $* *$ Significant at $5 \%, * *=$ Significant at $10 \%$.

It could be understood from the table. 4 that age, innovativeness and occupation had non-significant association with the knowledge of the farmers about recommended mentha cultivation practice. Meanwhile, education, land holding size, mass media exposure, social 


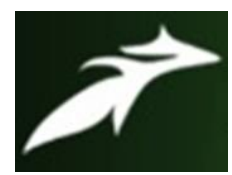

Ravi Prakash Verma et al, International Journal of Advances in Agricultural Science and Technology, Vol.8 Issue.8, August-2021, pg. 16-32

ISSN: 2348-1358 Impact Factor: 6.057

NAAS Rating: 3.77

participation, economic motivation, risk orientation and extension contact had positive and significant association with the knowledge of the farmers about recommended mentha cultivation practices at 5 per cent level of probability. In addition to this, annual income and farming experience had positive and significant association with the knowledge level of the farmers about recommended mentha cultivation practices at 10 per cent level of probability.

Table 7. Association between the independent variables and adoption level of the farmers about recommended mentha cultivation

\begin{tabular}{|c|l|c|c|c|c|}
\hline S. & \multicolumn{1}{|c|}{ Characteristics } & 'r' value & Regression & Standard & t-value \\
No. & & & co-efficient & & \\
\hline $\mathrm{X}_{1}$ & Age & -0.367 & -0.677 & 0.258 & 0.459 \\
\hline $\mathrm{X}_{2}$ & Education & $0.101^{* *}$ & $2.519^{*}$ & 1.374 & $0.073^{*}$ \\
\hline $\mathrm{X}_{3}$ & Land holding size & $0.035^{*}$ & $0.450^{*}$ & 3.465 & $0.056^{*}$ \\
\hline $\mathrm{X}_{4}$ & Occupation & 0.690 & 0.110 & 1.429 & 0.939 \\
\hline $\mathrm{X}_{5}$ & Annual income & 0.415 & 6.995 & 4.367 & 0.689 \\
\hline $\mathrm{X}_{6}$ & Farming experience & $0.010^{*}$ & $-2.965^{*}$ & 1.184 & $0.016^{*}$ \\
\hline $\mathrm{X}_{7}$ & Mass media exposure & $0.038^{*}$ & $-4.072^{*}$ & 1.637 & $0.017^{*}$ \\
\hline $\mathrm{X}_{8}$ & Innovativeness & 0.769 & 4.987 & 0.110 & 0.939 \\
\hline $\mathrm{X}_{9}$ & Social participation & $0.049^{*}$ & $5.876^{*}$ & 3.547 & $0.034^{*}$ \\
\hline $\mathrm{X}_{10}$ & Economic motivation & $0.037^{*}$ & $7.584^{*}$ & 1.524 & $0.023^{*}$ \\
\hline $\mathrm{X}_{11}$ & Risk orientation & $0.041^{*}$ & $4.065^{* *}$ & 5.590 & $0.471^{* *}$ \\
\hline
\end{tabular}




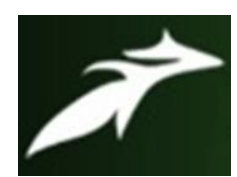

Ravi Prakash Verma et al, International Journal of Advances in Agricultural Science and Technology, Vol.8 Issue.8, August-2021, pg. 16-32

ISSN: 2348-1358

Impact Factor: 6.057

NAAS Rating: 3.77

\begin{tabular}{|c|l|l|l|l|c|}
\hline $\mathrm{X}_{12}$ & Extension contact & $0.027^{*}$ & $6.372^{* *}$ & 0.000 & $0.131^{* *}$ \\
\hline
\end{tabular}

$\mathrm{R}^{2}=0.51$

$\mathrm{F}=3.489$

$\mathrm{a}=151.677$

NS = Not Significant $*=$ Significant at $5 \%, * *=$ Significant at $10 \%$.

It could be understood from the table.4.23, that age, occupation, annual income and innovativeness had non-significant association with the adoption of the farmers about recommended mentha cultivation practices. Meanwhile, land holding size, farming experience, mass media exposure, social participation, economic motivation and risk orientation had positive and significant association with the adoption of the farmers about recommended mentha cultivation practices at 5 per cent level of probability. In addition to this, education and extension contact had positive and significant association with the adoption level of the farmers about recommended mentha cultivation practices at 10 per cent level of probability.

\section{Conclusion}

It is concluded that higher percentage of the mentha growers were middle aged $(81.70 \%)$, followed by young age $(11.70 \%)$ and old age $(6.60 \%)$. Nearly half of the respondents had primary and secondary level of education $(46.60 \%)$, followed by high school $(21.70 \%)$ and illiterate $(21.70 \%)$ and graduate and diploma (10\%).81.70 per cent of the mentha growers took agriculture as their main occupation, whereas only 18.30 per cent of the mentha growers considered business + service as their subsidiary occupation. Higher percentage of the mentha growers had a land holding of below 1 hectare $(41.70 \%)$, followed by land holding of more than 1-2 hectares (38.30\%), had holding of more than 2-3 hectare (20\%).Higher percentage of the mentha growers had medium level of annual income $(68.30 \%)$, followed by high (16.70\%) and low (15\%).Most of the respondents had medium farm power $(61.70 \%)$, followed by low farm power $(20 \%)$ and high farm power $(18.30 \%)$.More than half of the respondents $(58.40 \%)$ had medium level of source of information, followed by low (23.30\%) and high (18.30\%) level of source of information.45 per cent of the respondents had membership in one organization, followed by 33.30 per cent of the respondents had no membership in any organization, 20 per cent of them had membership in more than one organization and only 1.70 per cent of the respondents were office bearer. 58.33 per cent of the mentha growers had medium level of extension contact, 


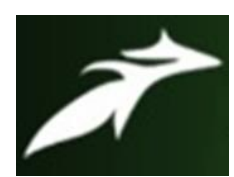

Ravi Prakash Verma et al, International Journal of Advances in Agricultural Science and Technology, Vol.8 Issue.8, August-2021, pg. 16-32

ISSN: 2348-1358

Impact Factor: 6.057

NAAS Rating: 3.77

followed by 28.33 per cent of them had low level of extension contact and only 13.33 per cent of them had high level of extension contact. Most of the respondents had low level of innovativeness (68.30\%), followed by medium (26.70\%) and high (5\%) level of innovativeness .Half of the respondents had low level of mass media exposure $(50 \%)$, followed by medium (40\%) and high (10\%) level of mass media exposure. More than half of the respondents had medium level of economic motivation $(51.70 \%)$, followed by low $(25 \%)$ and high level of economic motivation (23.30\%).Most of the respondents had medium knowledge $(51.70 \%)$, followed by low level of knowledge $(33.30 \%)$ and high level of knowledge (15\%).Most of the respondent had medium level of adoption (66.70\%), followed by low level of adoption (21.70\%) and high level of adoption (11.60\%).

\section{References}

[1]. Anil Kumar. 2017. Socio-economic aspects of menthol mint cultivation in the districts of Uttar Pradesh. Indian Journal of Scientific Research. 16(2):13-18.

[2]. Anurag Awasthi. 2017. A study on production and marketing of mentha in Lakhimpur Kheri district of Uttar Pradesh. M.A.B.M. thesis. BHU, Varanasi.

[3]. Bahl, J.R., Kumar, S., Bansal, R.P., Gupta, A.K., Singh, V. and Sharma, S. 2002. High economic returns from compansion and relay cropping of Bread, Wheat and Menthol mint in the winter-summer season in North Indian plains. Industrial crops and products. 15 (2):103-114.

[4]. Choudhary, H., Badal, P.S., Singh, V., Osti, R. 2017. Marketing of menthol mint in Uttar Pradesh. International journal of Pure and Applied Bioscience. 5(6):1323-1327.

[5]. Gurvinder Singh, Manmeet Kaur. Problems of summer mungbean cultivation in Punjab state. Multilogic in science. 2018;8:367- 369.

[6]. Harshika Choudhary. 2013. An economic analysis of mentha cultivfation in Rampur district of Uttar Pradesh. M.Sc., Thesis. G.B. Pant university of Agriculture and Technology, Pantnagar, Uttarkhand.

[7]. Ramachandra KV. Farmers knowledge level and adoption behaviour about the nutrient management in cabbage-potato cropping system in kolar district of Karnataka. M.Sc Thesis, University of Agricultural Sciences, Bangalore; 2002.

[8]. Ramkant. 2015. A study on production and markting of mentha in phoolebehar block of lakhimpur kheri district Uttar Pradesh. M.A.B.M. Thesis. BHU, Varanasi.

[9]. Verma, R.K., Chauhan, A., Verma, R.S., Rahman, L.U., and Bisht, A. .2008. Improving production potential and resources use efficiency of peppermint (Mentha piperita L.,) int3ercropped with Geranium (Pelargonium graveolens L., Herit ex Ait) under different plant density. Industrial Crops and Products. 44(4):577-582. 